\title{
Chapter 10 \\ A Gay Neighborhood or Merely \\ a Temporary Cluster of "Strange" Bars? \\ Gay Bar Culture in Antwerp
}

\author{
Bart Eeckhout, Rob Herreman, and Alexander Dhoest
}

\begin{abstract}
This chapter investigates the historical permutations of those areas that come closest to qualifying as lesbian and gay neighborhoods in Antwerp, the largest city in Flanders (the northern, Dutch-speaking part of Belgium). Although Antwerp has come to be represented as the "gay capital" of Flanders, it never developed a fullfledged gay neighborhood in the Anglo-American tradition of the concept. The clustering of sexual minorities in the city has been limited largely to the economic, social, and cultural business of (nightlife) entertainment, with lesbian and gay meeting places historically concentrating in particular neighborhoods that, moreover, have shifted over time and dissipated again. The chapter's fine-grained analysis intends to reveal geographic, social, and cultural specificities for which a more detailed understanding of both the Antwerp and the Belgian contexts is necessary. Its tripartite structure is shaped by the specific heuristic conditions set by it. Because the larger historical context for the investigated subject remains to be written, the chapter first undertakes a substantial and panoramic survey of the emergence of gay nightlife in Antwerp during the early half of the twentieth century. This provides the framework needed for a more detailed analysis in the second part, which zooms in on an area in the immediate vicinity of the Central Station and takes as its emblematic focus one sufficiently long-term and iconic gay bar, called Café Strange. Finally, the chapter zooms out again to sketch how even such a limited gay nightlife cluster in Antwerp has evaporated again in the course of the twenty-first century, leaving a landscape that is hard to map and largely virtual.
\end{abstract}

Keywords Antwerp $\cdot$ Belgium; gay bars $\cdot$ Flanders $\cdot$ Gay neighborhoods

\footnotetext{
B. Eeckhout $(\varangle) \cdot R$. Herreman · A. Dhoest

University of Antwerp, Antwerp, Belgium

e-mail: bart.eeckhout@uantwerpen.be

R. Herreman

e-mail: rob.herreman@gmail.com
}
A. Dhoest
e-mail: alexander.dhoest@uantwerpen.be 


\subsection{Introduction}

This chapter proposes to investigate what historiographers would call the "long twentieth century" of lesbian and gay neighborhoods in the specific context of Antwerp, the largest city in Flanders (the northern, Dutch-speaking part of Belgium). ${ }^{1}$ Although Antwerp has come to be represented as the "gay capital" of Flanders, we will show that it never developed a full-fledged gay neighborhood in the Anglo-American tradition of the concept - that is, a neighborhood characterized by the historical clustering of a wide range of urban functions for sexual minorities (social, cultural, residential, sexual, commercial, with service and hospitality industries as well as entertainment venues). As in several other Western European nations (and many non-Western countries besides), the clustering of sexual minorities in Antwerp has been limited largely to the economic, social, and cultural business of (nightlife) entertainment, with lesbian and gay meeting places historically concentrating in particular neighborhoods that, moreover, have shifted over time and dissipated again. This pattern is a familiar one from the history of modern sexual identity formation. As the identity of modern-day "homosexuals" came to be shaped and solidified (roughly as of the second half of the nineteenth century), people who identified increasingly as members of this demographic created private, semi-public, and public meeting spaces for themselves, starting in larger cities such as Berlin and New York (Beachy 2014; Chauncey 1995). Bars and clubs became the principal spaces for escaping from social norms and invisibility, as well as for exploring same-sex attraction and alternative gender expressions. While the emergence of the same kind of venues in Antwerp is thus characterized by social and material parameters that, at a sufficiently high level of abstraction, apply to many other cities in Western Europe (and, again, beyond), the more fine-grained analysis we intend to offer will inevitably reveal geographic, social, and cultural specificities for which a more detailed understanding of both the Antwerp and the Belgian contexts is necessary.

A few aspects of this culturally specific context may be worth highlighting in advance. Whereas in the following discussion we will automatically resort to the term "neighborhood" as an established concept in the field of urban studies that is crucial to a volume such as this, we will frequently alternate it with the less strongly connoted term "area." This will be mainly to avoid habitual associations with the notion of a neighborhood simply being projected onto the terrain we are discussing. For various historical, sociopolitical, economic, and cultural reasons, the social and material granularity of Belgian cities is quite different from what is to be found in most North-American (and a lot of English-speaking Commonwealth) cities. Belgian urban neighborhoods tend to be more finely grained and mixed, more complex in their stratifications and less homogeneous, and as a result do not invite the same strong sense of individuality and identity as do many of the iconic neighborhoods in

\footnotetext{
${ }^{1}$ Throughout this chapter, we will use the shorthand terms "lesbian and gay" or merely "gay" as they seem best suited to serve as historical umbrella terms for the core identity categories analyzed across the period under discussion, even if they are anachronistic when applied to the period before the 1970s and too limitative for the twenty-first century.
} 
the English-speaking world, which are underwritten by a more outspoken logic of demarcation and differentiation. A basically historical, midsize city such as Antwerp, moreover, is defined by a relatively small core that allows for a close mixing of functions. This means, among other things, that different parts of the city are easy to reach, whether on foot, by bicycle, or through public or private transportation. A self-chosen, not-economically enforced residential clustering of one segment of the population in one specific area-lesbians and gays in our historical shorthand description-has thus never seemed as necessary or enticing as in much bigger cities abroad.

To this should be added a larger cultural context: Flanders as a whole is a densely populated region in which especially the triangle Antwerp-Ghent-Brussels has sometimes been described, in comparative international terms, as a single extended conurbation (GUST 1999: 32-38; Albrechts and Lievois 2004). For a complex combination of historical, sociopolitical, economic, and cultural reasons again, Flemings have tended to be less mobile in their residential careers than citizens in most other modern nations; to this day, they still frequently prefer to stick to the area where they were born. This cultural pattern is so deeply ingrained that it applies even to lesbians and gays in the days of massive anti-homosexual hostility in rural Flanders, when one would have expected a great many of them to engage in the same kind of "reverse diaspora" (Sinfield 1996: 281) to central cities that has been historically characteristic of sexual and gender minorities in other countries. Throughout the period under discussion, in fact, a large number of Flemish lesbians and gays continued to live in their immediate native areas and simply commuted into a city such as Antwerp for their nightlife entertainment (Vincke et al. 2006). Thus, as a rule, the users of the gay-specific facilities we will be describing were arriving from anywhere in the city or, as it turns out, beyond. They did not build most of their lives around a specific, recognizably gay neighborhood, but made occasional use of the clusters of bars that over time became available in Antwerp.

Before we are able to embark on the following narrative and analysis, it is also necessary to reflect methodologically on how our investigation is shaped (both enabled and restricted) by its heuristic conditions. Belgium is a small country fractured still further by the cultural divide between its two main linguistic communities (French- and Dutch-speaking). The scale limit has notable repercussions for the academic availability of empirical data. Among other things, the country has not developed a viable market for academic publications catering to the niche interest of sexual and gender minorities. Partly as a result, no truly encompassing history of such minorities has been published so far, whether for the country as a whole or for the region of Flanders, even though a number of attempts at presenting capita selecta from this history have recently been made (Borghs 2015; Dupont 2015; Dupont et al. 2017; Hellinck 2002). It should come as no surprise, then, that Antwerp's lesbian and gay history remains to be written. Because none of the current chapter's three authors, moreover, are themselves trained historians (they are, respectively, a literary scholar specializing in American literature, a musicologist, and a media scholar), what this case study is about to present constitutes a first gathering of available data that should ideally be followed up by more extensive historiographical research. Some of the 
source materials for the following evocation will be, in fact, non-academic; they consist of archival findings by the second coauthor as part of his research project on musical cultures in Antwerp ${ }^{2}$; some of the informal interviews he conducted in this context; the cultural experience and knowledge of all three authors as participatory observers in Flemish/Antwerp society; and the authors' wider reading in various disciplinary fields and relevant publications.

The tripartite structure assumed by our case study is shaped by these conditions. Because the larger context for our subject remains to be written, it will be necessary, first, to undertake a relatively substantial and panoramic survey of the emergence of gay nightlife in Antwerp during the early half of the twentieth century. This will provide the framework needed for a more detailed analysis in the second part, which will zoom in on an area in the immediate vicinity of the Central Station and will take as its emblematic focus one sufficiently long-term and iconic gay bar, called Café Strange. Finally, we will zoom out again to sketch how even such a limited gay nightlife cluster in Antwerp has evaporated again in the course of the twenty-first century, leaving a landscape that is hard to map and largely virtual.

\subsection{The Emergence of a Gay Bar Culture in Antwerp}

While generally same-sex sexuality was severely punished from the Middle Ages until the French Revolution in the region currently known as Belgium (Dupont et al. 2017; Hofman 2017; Roelens 2018), in 1795 the same region became a part of France, where "sodomy" was subsequently removed from the penal code. Neither the French penal code of 1810 that was adopted in Belgium after the country's independence in 1830 nor the Belgian penal code of 1867 prohibited homosexual acts between consenting adults in private, although public displays of homosexual interest and desire could be prosecuted for "assaults on honor and public decency" (Vanhaelewyn 2008: 248). This implies that for much of the nineteenth and twentieth centuries, Belgian homosexuals were not as strongly persecuted as in many other European countries, though the fact that they were not actively oppressed by the State may also have slowed down lesbian and gay identity formation and social activism, especially in the largely Dutch-speaking and devoutly Catholic Flanders, where a conservative social value system persisted well into the second half of the twentieth century (Dupont et al. 2017). Throughout this period, same-sex sexuality was not publicly acknowledged, let alone socially accepted. Partly as a result, gay life remained very much underground and has become hard to retrace from official sources frequently used by historiographers in other countries, such as police files (Dupont 2015).

Indeed, the most important source of information that we have about everyday lesbian and gay life in the early to mid-twentieth century consists of a number of

\footnotetext{
${ }^{2}$ Some 70 LGBT and feminist commercial and political magazines published in Flanders between 1960 and 2010 as well as a collection of ca. 1000 flyers of events in the city.
} 
autobiographies and oral history interviews with lesbians and gays. ${ }^{3}$ These tell us that same-sex attraction and sexuality were nearly invisible within Belgian society at large and, as a result, barely existed as concepts or possible realities in the minds of most citizens. The topic was hardly ever brought up in families, schools, or the media, and received but little attention in medical and psychiatric circles. If Flemings ever heard allusions being made to homosexuality at all, it would have been in negative terms. For those experiencing same-sex desire, this meant that many could not name their feelings in the first place, felt abnormal, sinful, and/or perverse, and considered it much safer to remain silent about their sexual orientation. At most, they would look for answers in books, secretly visited a doctor, or searched around in anonymous urban environments until they found bars where it seemed possible to meet like-minded people. If they came to have sexual or romantic relations at all, it was behind closed doors or in transient urban spaces that made sexual cruising materially possible. With very few exceptions, they would refrain from disclosing their sexual orientation to family, friends, neighbors, and/or colleagues, nor did they assume a positive identity label for themselves; the coded language used by and for them would be characterized by a strategic vagueness and imprecision: they were "like that," "for the women," or "for the men," or "belonged to the family."

Although invisibility and silence thus reigned supreme in mainstream Flemish society, from the early twentieth century onwards some form of gay subculture did start to emerge tentatively in out-of-the-way pockets, and it was Antwerp, in particular, that began to develop something that might qualify as a gay nightlife (Hellinck 2002: 6). For those who could find their way to them, the semi-public spaces of a handful of bars came to offer a haven where patrons could be more at ease, meet other lesbians and gays, explore non-normative gender expressions, make friends, and find lovers. In Antwerp, the epicenter of this budding gay subculture was situated in the so-called Skippers Quarter (Schipperskwartier), which bordered on the harbor. ${ }^{4}$ The location is no coincidence: it was arguably the city's least Flemish and most transient space characterized by constant transnational flows of goods and people. The natural geography of the river Scheldt, whose extended estuary connects Antwerp to the North Sea, had allowed the city to become for several centuries Europe's prime inland port. From the moment the river's quays were straightened in 1885, the Skippers Quarter became a defining neighborhood in the city (Lampo 2002). It acquired its distinct, bustling character from the fact that it was closest to where freighters docked and where, among other things, the Red Star Line transported hundreds of thousands of travelers to and from the US in the decades around the turn of the twentieth century. A large number of businesses flourished in this quarter, including cafés and temporary lodgings for sailors and travelers, as well as venues

\footnotetext{
${ }^{3}$ This account is based on David and Meyntjens (2009), Kegels (2006, 2008), Van den Heuvel (2009) and Winters (2011).

${ }^{4}$ The name is translated differently in different sources, e.g., as Sailors' Quarter in Loopmans and Van Den Broeck 2011. Since the antiquated Dutch word schipper does not quite overlap with the more recent term sailor, and since the English word skipper is precisely derived from the Dutch schipper, we have chosen to remain close to the Dutch original by translating the area as Skippers Quarter.
} 
for prostitution (Lampo 2011). Loopmans and Van Den Broeck (2011) have in fact traced the roots for such typical harbor prostitution much further back in history, calling the area one of the oldest red-light districts in Europe, whose origins lie in the fifteenth century.

It is here, near the river and the harbor, that Antwerp's gay nightlife most probably first took shape. According to Armand Everaert, the owner of Café Strange (to which we will turn in a moment), at least the ill-reputed neighborhood of the Skippers Quarter, with its red-light district, guaranteed a modicum of anonymity (Hellinck 2015). Not only situated at the geographical margins of the city, the neighborhood also occupied a social position at the margins of respectable mainstream society. By the same token, it could offer a refuge and free port for non-normative forms of sexuality and gender expression. Yet, while we may be certain that same-sex sexual practices took place there, it is not so clear whether the area already witnessed a minimally organized form of homosexual subculture during the late nineteenth century, and if so, whether this was then integrated in the established business of heterosexual prostitution. In his semi-autobiographical novel of 1888, La Nouvelle Carthage, the Francophone Flemish writer Georges Eekhoud at one point describes a "crystal palace" (palais de crystal) in the red-light district of Antwerp. The interior, which is evoked as a cave full of mirrors, is described in detail, and the description suggests that the writer's inspiration was the renowned luxury brothel in the Skippers Quarter called Crystal Palace (Min 2011: 214-215). Eekhoud, who was a brave early voice in the literary description of same-sex desire, probably visited the place, and in his novel he suggests that "all stages of debauchery" took place there. Yet his description leaves unclear whether this also involved same-sex practices.

For the early half of the twentieth century, there is evidence, at least, that drag performances had begun to take place in the Skippers Quarter. Thus, a woman by the name of Bertha (born in 1916) remembers that a friend took her to a transvestite bar at the age of sixteen (David and Meyntjens 2009: 24). Perhaps they visited a "binge café," where the staff-mostly women and/or men in drag-tried to tempt the male clientele to drink as much as possible (De Graef 1973). One such place was Danny's Bar, a notorious sailors' bar mentioned in the anonymous folk poem "One Hell of a Pub Crawl!" as a venue where the "she" appears to be very much a man. ${ }^{5}$ Both the owner, going by the nickname of "den Daan" (Danny Boy), and his male staff were dressed as women, and they took it upon them to seduce the sailors into binging uncontrollably. When "Marie," one of Daan's male staff members, later took over the bar, he and his wife continued to work as transvestites (Kegels 2008).

On the online forum "YO! Liverpool," a former sailor by the name of Brian Daley reminisces about his own later, postwar experiences at Danny's Bar. ${ }^{6}$ At the recommendation of a few older sailors, Brian and two of his friends visited the bar to "lose their cherries." His testimony, dated March 2008, is worth quoting at some

\footnotetext{
${ }^{5}$ See http://www.merchant-navy.net/forum/poetry-and-ballads/29047-hell-pub-crawl.html, last accessed 18 June 2019.

${ }^{6}$ See http://www.yoliverpool.com/forum/showthread.php?5415-Hullo-Old-Home\&p=125649\& highlight=Danny\%27s+Bar\#post125649, last accessed 2 January 2020.
} 
length (with corrected punctuation for the sake of readability) because it allows us to immerse ourselves in this bygone world:

There it was! Danny's Bar, the bright green neon lighting the way to heaven. It was only about 8.00 p.m. and the streets were not yet crowded; we entered the bar and were almost blinded by the lights and mirrors, chrome and dark mahogany and brass. The most beautiful women that I had seen this side of the silver screen sat at the tables around the bar. There were no men in there, just us three boys. There was a Lana Turner lookalike in an off-the-shoulder gown, her pale skin and generous bosom thrusting at the front of her dress; there was Jane Powell, and Rhonda Fleming too. The guys had been telling the truth; and they wanted to sit with us!! Oh heaven, this surely was Fiddlers Green. So there we were, a lady by each of our sides and they were buying our drinks. Somebody put a record on the jukebox and Lana took my hand and led me to the floor. She took a firm hold of me, pressing her body into mine; should I kiss her? Her perfume and the feel of her bosom thrusting into my chest had my hormones running wild. Her husky continental accent, sounding like Marlene Dietrich, had my trousers near at bursting point; she knew [this] and whispered into my ear. "You want to make love, Dollink?" she asked, rasping her five o'clock shadow against my virginal cheek. AAAARRGH!!!!! Lana was a Laddie, not a lady. We three made our discovery almost simultaneously; as we shot to the door, we could hear Danny laughing his head off. "Good night, Darlings," he cried after us.

Brian's adventure was apparently part of a tradition built up over the years. By way of a joke, older sailors would recommend Danny's Bar to inexperienced newcomers; sometimes they would join them to watch the results. A few years after Brian's first experience, it was his turn to initiate two younger fellow-sailors, Eddy and Terry. In a follow-up recollection, posted in November $2008,{ }^{7}$ Brian explains how this mission went awry when his drink was drugged and he woke up in bed with a "lady."

As these anecdotes illustrate, clients were frequently made to get drunk, sometimes drugged, in order to make them spend as much money as possible and even end up in bed with one of the "girls" (Kegels 2008). For sailors, a visit to Danny's Bar could be a hazing ritual, though in some cases it may have served as a site of sexual and gender exploration as well. Jack De Graef (1973: 104-105) describes the story of a man who spent the evening and night with a professional transvestite, and was brought home the next day by taxi-broke, tired, and with memory problems. While undressing him, his wife discovered he was wearing women's panties (Fig. 10.1).

The gay clientele of the Skippers Quarter steadily grew; on the eve of the Second World War, the neighborhood had apparently acquired a distinctly gay connotation to those in the know. By then, among other changes, the Crystal Palace brothel had been transformed into a gay bar (Kegels 2008; Min 2011). In the postwar years, however, the bars where lesbian and gay patrons could meet up started to spread beyond the Skippers Quarter. Though a few of these opened in the historical center, in the area around the Cathedral and City Hall, most of the new venues sprang up in the area close to the Central Station, the grandly sculpted railroad terminal for commuters to the east of the city center. These were in general small operations; the most famous among them were called Shakespeare (in the historical center) and Café Strange, Fortunia, Week-End, and La Ronde near the train station. Since most of such bars were a clear

\footnotetext{
${ }^{7}$ See http://www.yoliverpool.com/forum/showthread.php?5415-Hullo-Old-Home\&p=155101\& highlight=Dannys\#post155101, last accessed 2 January 2020.
} 
(a)

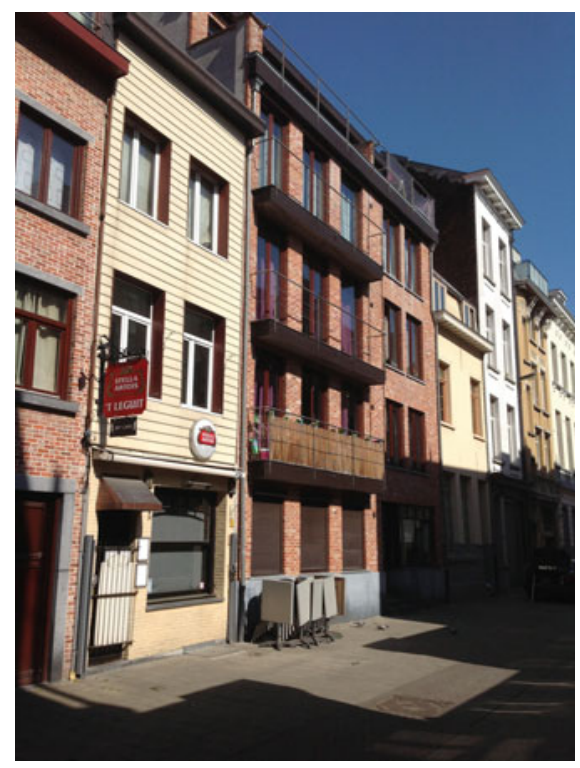

(b)

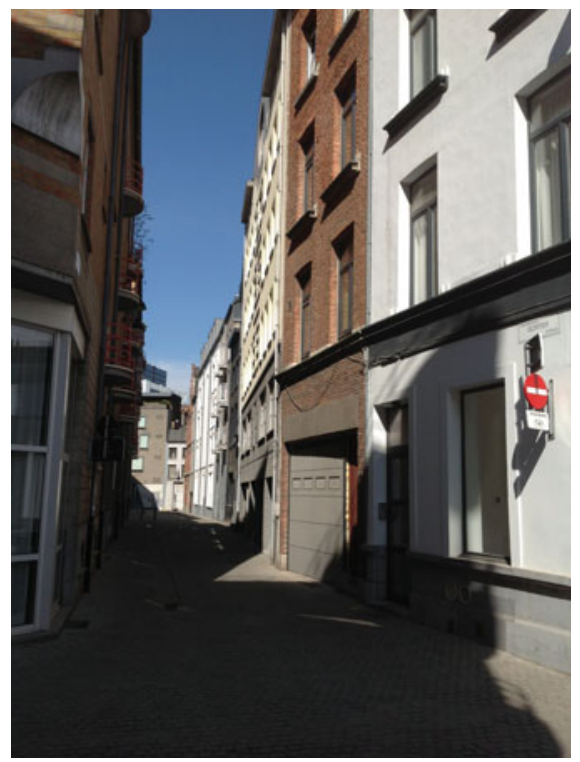

Fig. 10.1 The invisible gay history of the Skippers Quarter: where for most of the twentieth century Danny's Bar used to be (until the mid-1990s), today a stretch of new-built residential houses and a brasserie are to be found (left), and in the historically narrow alley where the Crystal Palace used to be (until the building collapsed in the 1960s), bland architecture now reigns supreme (right) (Source Images by Bart Eeckhout, April 2020)

distance from the Skippers Quarter, they attracted a different clientele, though some sailors and sex workers would visit the nearest one, Shakespeare, until the 1960s (David and Meyntjens 2009: 143-144). There was a gender difference in patrons as well. Whereas Shakespeare had a female bartender, Jackie, and attracted a mostly female crowd, the bars near the train station had male bartenders and clientele: "Dikke Piet" (Fat Pete) was the gay bartender of Fortunia, "Miss Banaan" (Miss Banana) served at Week-End, and the drag queen "Eddy"/“Edith" at La Ronde (Winters 2011: 56-58; Kegels 2008: 37-38, 64, 89-90).

As of the 1950s, the names of such new bars more often contained coded references to homosexual culture. Older bars' names in the Skippers Quarter that had already been in operation before they attracted a gay clientele would sometimes refer to the harbor location (De Lichttoren [The Lighthouse]), to a region (Café Normandie), the bar's owner (Danny's Bar), or the venue's interior design (Crystal Palace). Of these, only Pigalle had a sexual connotation, because it conjured up the Parisian neighborhood around Place Pigalle in Montmartre, famous for its sexual and erotic nightlife (including the iconic Moulin Rouge cabaret). The newer bars springing up in other Antwerp neighborhoods occasionally sported more allusive if ambiguous names that carried various overtones for insiders. For instance, "Shakespeare" evoked both the world-famous playwright (whose love sonnets, some connoisseurs began 
to realize, principally courted a mysterious young man) and a Dutch lesbian and gay organization by the same name. When one of the gay bars in the vicinity of the station, Week-End, changed owners in the late 1950s, it was renamed as La Vie en Rose (Pink Life), thereby alluding not only to the eponymous song by Edith Piaf, the French singer who was then becoming a cult diva among homosexuals, but also to the growing symbolism of the color pink, which, under the influence of American clothes manufacturers, had come to be reserved almost exclusively for young girls and thus carried a strong feminine connotation (Paoletti 2012). The bar's conspicuously gendered name, in combination with its location, signaled its status to a gay clientele.

Meanwhile, the older bars in the Skippers Quarter began to be closed, at first slowly in the 1960s, when the streets behind the City Hall were renovated, and more drastically in the mid-eighties, when much of the neighborhood was modernized by town planners, and its former occupants, particularly sex workers, were pushed to the north, away from the backstreets bordering on the historical center and toward the modern harbor and docks (Loopmans and Van Den Broeck 2011). It is there that a new generation of larger gay-friendly bars and clubs came to take root, such as Hessenhuis (opened in 1993) and Red \& Blue (opened in 1998). As before, such slight geographic displacements were relevant only to the location of bars and clubs, because the local lesbian and gay population as a rule had not sought to move into any of these neighborhoods and had not set up a community life, service sector, or cultural industry in them (Fig. 10.2).

\subsection{The Paradigmatic Case History of Café Strange in the Central Station Area}

So far, we have limited ourselves largely to a bird's-eye view of the permutations of twentieth-century gay nightlife in Antwerp as it originated in the Skippers Quarter and, in the second half of the century, moved to additional neighborhoods. From its early roots in an environment of cultural marginality, clandestine behavior, drunken sailors, and ambiguously gendered sex workers, such nightlife was gradually transplanted to a somewhat less ill-reputed (if still predominantly working-class and transient) neighborhood near the city's Central Station. Café Strange offers a fine example to elaborate this move in some architectural and social detail. Because of the venue's longevity, moreover (it still survives), it presents a sufficiently extended case study that allows us to ponder the twenty-first-century decline of gay bar life in Antwerp as well.

In 1955, a gay-friendly bar in the Dambruggestraat, a street located near the popular neighborhood Seefhoek, was reopened by the gay couple Bruno and Julien (Kegels 2008: 112-113). The bar was renamed "Café Strange" (in English), clearly to act as a magnet on patrons who at the time were still often dismissed as "queer" in the anglophone world and did not yet have a language of collective pride as 


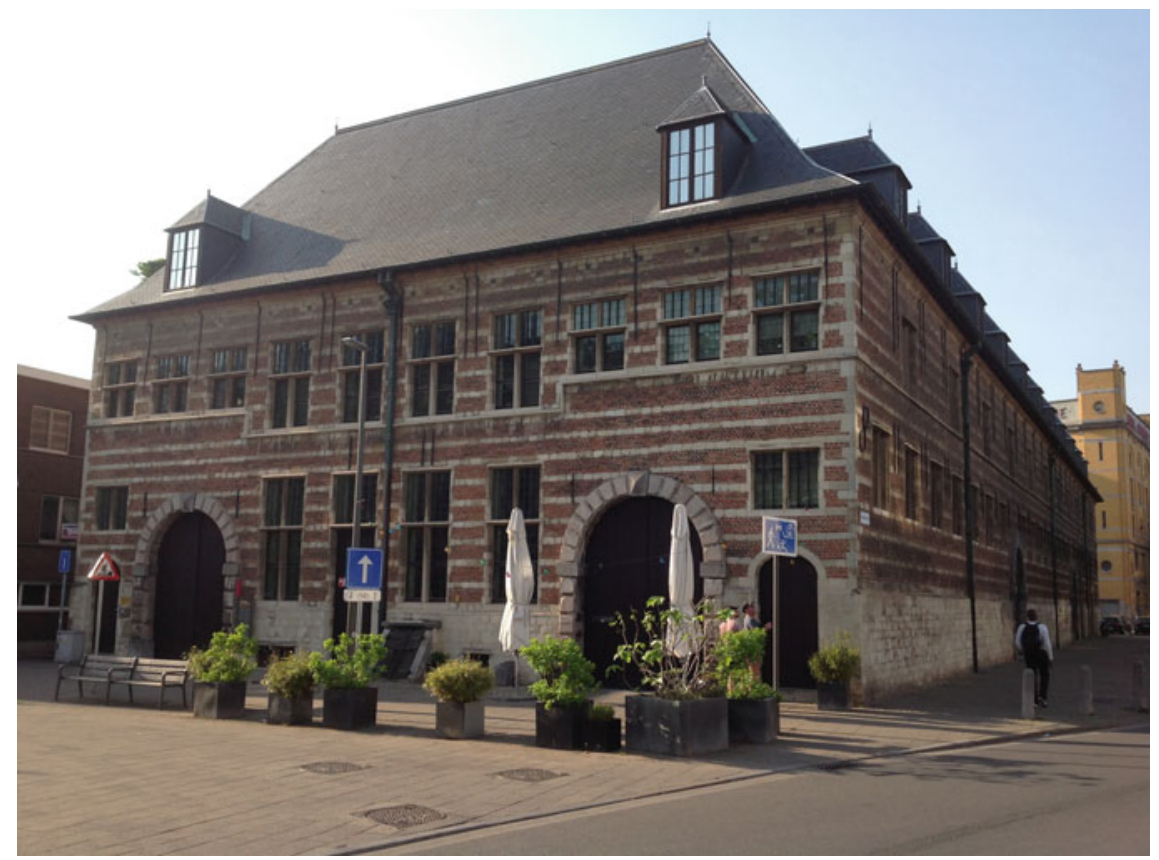

Fig. 10.2 The Hessenhuis, built in 1564, belongs to Antwerp's historical patrimony. After renovation in 1975 it reopened as a temporary exhibition space. Since 1993 it has also been housing a gay(-friendly) café/club catering to a younger crowd (Source Image by Bart Eeckhout, April 2020)

a sexual minority. At the time, the epicenter of gay life was probably still in the Skippers Quarter, yet by then the Dambruggestraat also happened to host the gay bar Fortunia, and the street was conveniently within walking distance from the station, with its daily crowd of national commuters and international travelers, as well as one of the largest and most notorious public toilets (in front of the station), where men were known to hook up and/or have sex with other men (Kegels 2008: 75-79).

Like Shakespeare, Café Strange was one of the local pioneers when it came to alluding to the kind of patrons it targeted, and the nature of the bar, through its very name. In response to the wider Flemish culture of secrecy about homosexuality, however, the name was still vaguely suggestive rather than explicit. In addition to the bar's name and location, prospective patrons were actively canvassed in due course through advertisements in publicly little-known subcultural media, such as the member magazine of BVSR, the Belgian Association for Sexual Justice (Belgische Vereniging voor Sexuele Rechtvaardigheid), one of the first Belgian LGBT associations, founded in 1965. At the same time, the owners had to remain discrete and safeguard the privacy of their patrons. In accordance with customs at the time, curtains were used to prevent passersby from looking in through the windows, and patrons had to knock or ring a bell to get in, as the entrance door was frequently closed. Like many other such bars, Café Strange sported a separate porch at the 
entrance, whose purpose was to avoid patrons making themselves too visible when they entered and exited. This architectural idiosyncrasy survives today, as the bar still has three entrance doors: one in the front, which is unlocked only when the owner arrives, and two in a porch providing access either to the bar or to the apartments above. According to the current proprietor, Armand, the first gay owners, Bruno and Julien, made a great effort to change the place when they bought it, and it is likely they replaced the main entrance to adapt the bar to the desires of patrons.

Café Strange first opened as "Brasserie Strange," which in the Belgian context implies that both food and drinks were served. As it became increasingly popular over the years, the owners were forced to enlarge the main room. The interior was changed once more when additional gay bars and discos opened in the neighborhood. Bruno and Julien gave Café Strange a look that was similar to such competitors, both by adding a large buffet at the end of the room, close to the courtyard, and by moving seats against the wall to provide enough space for dancing. One visitor from those years recalls it as a nice place with friendly staff (Kegels 2008: 66, 112). Even so, by the end of the 1970s, Café Strange faced a series of difficulties. After Bruno had died, his partner Julien took over from 1977 to 1979, but he got himself involved in dubious relationships that ended dramatically by his getting killed (Daems 2010: 4). By then, the international gay travelers' guide Spartacus was warning its readers about the presence of rent boys mixing among the mostly elderly gay men. ${ }^{8}$ In 1980 , after undertaking some minor renovations, another gay couple took over, Armand and Roger. Their purpose was to carry on the tradition of Café Strange as a gay bar. They painted the building's façade pink and added a drawing of a sexy sailor as a symbol, thereby referencing gay culture and erotica more openly. Inside, pictures of semi-naked and naked men were hung on the walls. The new owners moved the large buffet to the front and added two couches there. Several gay bars, again, had this kind of set-up. Among other things, it allowed the owner or bartender to open the door quickly when someone was waiting outside, or to keep an eye on patrons walking in when the door was open. At the same time, those who were sitting on the couches had a practical way of checking out whoever came in (Fig. 10.3). ${ }^{9}$

The new owners, who were experienced entrepreneurs, continued to promote the business as a bar as well as a discotheque with room to dance, but they were looking to attract more customers as well. Instead of sticking to the traditional jukebox, they acquired a professional DJ set with turntable, hired DJs to ensure that a continuous flow of music was being played during parties, bought new recordings on a regular basis, and advertised in both national and international LGBT media-for instance, in the much-read Dutch Gay Krant and international guides such as Spartacus. Furthermore, they produced a magazine called Antwerp Gay Plan with information about gay leisure in the city and personal stories, among other things.

Their approach was successful. The place developed the reputation of being at once modern, popular, and low-key (De Bie 2012; Everaert 2014). The atmosphere

\footnotetext{
${ }^{8}$ See, e.g., the 1979 edition of the Spartacus International Gay Guide, p. 53.

${ }^{9}$ This information is based on an interview with Armand, conducted by the second author on 27 January 2014.
} 


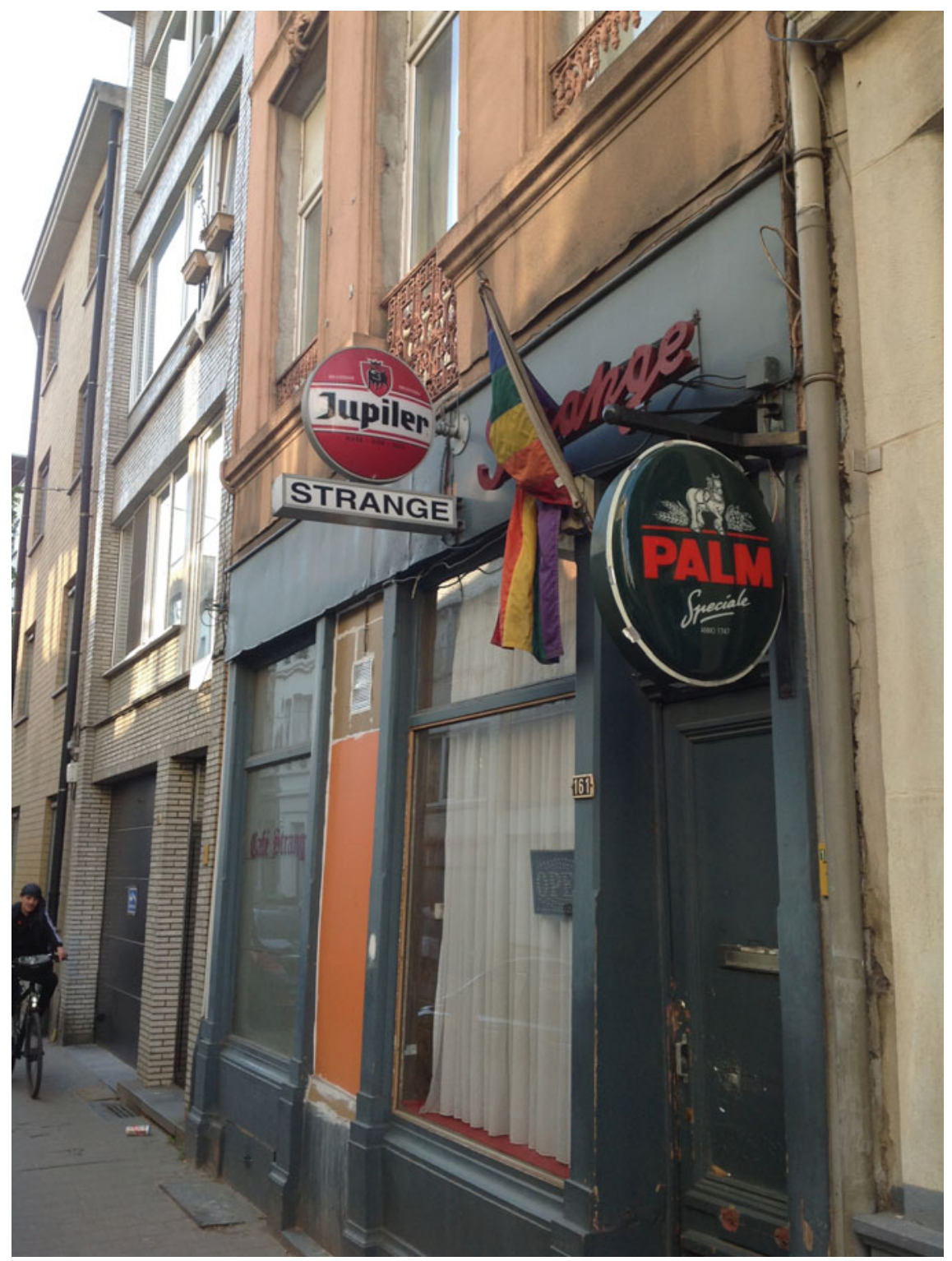

Fig. 10.3 Café Strange in the Dambruggestraat. The salmon-colored façade has lost much of its former pink glamor. Note the old-fashioned device behind the window that lights up to signal that the bar is open (Source Image by Bart Eeckhout, April 2020) 
seems to have been unpretentious and folksy, in accordance with the baseline of the ads the bar placed at the time: "casual, happily free, cosy" ("losjes, vrij en blij, gezellig"; De Homokrant 1982, ed. 9, p. 27). Armand and Roger frequently threw parties to celebrate special occasions and traditions, such as their birthdays, carnival, Saint Nicholas Day, New Year's Eve, and Easter. These tended to follow lightly scripted formats that usually involved dressing up to a theme (e.g., prostitution, opera and operetta, the fifties), with the best-dressed visitors receiving at times remarkably expensive prizes. For instance, a flyer announcing the carnival ball for 1982 promises to winners a flight to Athens, a weekend to Amsterdam or Paris, or a dinner in an Antwerp restaurant, among other things. The announcement further mentions the owners' wish that patrons participate in the occasion with no holds barred: "the crazier the better," it says. Besides theme parties, there were more regular and ordinary events, such as "tea dances" (thé dansants) on Sundays, when, according to a 1985 ad in the Flemish gay newspaper De Homokrant, a DJ would play "golden hits, film music, and popcorn oldies" (ed. 2, p. 31). The majority of visitors to Café Strange appear to have been gay, lesbian, or bisexual, although national and international gay guides show that the demographic shifted over the years, from a relatively wider range in age and gender during the 1980s to a crowd of mostly gay men during the 1990 s, and then morphing into a mix of gay and gay-friendly patrons a decade later.

The bar stayed financially quite profitable until the 1990s, when the number of patrons began to dwindle. While Café Strange is still open at the time of writing (in 2020), most other gay bars in the area (and a good many cafés in general across the city) have closed. In an interview he gave in 2010, Armand claims that the number of gay bars in the Van Schoonhovenstraat, the main artery in the neighborhood, had by then already declined from 23 to three or four (Daems 2010: 5). ${ }^{10}$ Once again, the sense of a "gay neighborhood" had always been limited to a cluster of bars, by and large, although for a while this area close to the train station did contain a few community-oriented gay venues, too. The most important of these was the GOC (Gespreks- en Onthaalcentrum), one of the first Flemish LGBT associations, founded in 1968 under a blandly incommunicative name ("Conversation and Reception Center") borrowed from the earliest stages of the LGBT movement in the Netherlands. ${ }^{11}$ The GOC had a bar of its own in the Dambruggestraat, and as Armand recalls, whenever the organization's bar closed at 1 a.m., a good many of

\footnotetext{
${ }^{10}$ Archive research by the second author allows us to estimate the number of bars in the Van Schoonhovenstraat per decade. Although the last period, 2000-2010, suggests a thriving bar scene, these were mostly new bars which closed after a year or two.

Until 1960: 2.

1960-1969: 5 .

1970-1979: 22.

1980-1989: 35.

1990-1999: 24.

2000-2010: 23.

${ }^{11} \mathrm{See} \mathrm{http://www.holebipioniers.be/geschiedenis/de-eerste-stappen-naar-buiten,} \mathrm{last} \mathrm{accessed} \mathrm{on} 3$ January 2020.
} 
the patrons and staff tended to cross the street to extend the night at Cafe Strange (Daems 2010: 4).

\subsection{The Decline of Gay Bar Life in Antwerp}

There are many different reasons why commercial gay bar life in the area to the north of Antwerp's Central Station started to decline toward the end of the twentieth century until it has by now - two decades into the twenty-first century-all but disappeared. Some of these reasons are common to a logic that has characterized Western cities around the turn of the millennium in general; others are part of an even larger, global dynamic; only a handful seem to demand the same attention to specific and local players as we needed for painting the preceding portrait of twentieth-century bar life in the city.

We would nevertheless like to start this concluding section by taking the final category of reasons first, because we need it to understand the transition in sufficient detail. First of all, as the LGBTIQ movement in Flanders started to organize itself better (roughly as of the 1980s), it became effectively a growing competitor for the small commercial bars in central cities: a multiplying number of activist and community-building grassroots organizations, which also improved quickly at professionalizing their activities, depended heavily on the income they generated by organizing popular parties in bigger venues on a regular basis. For many young LGBTs interested in socializing on a larger scale and outside of commercial enterprises, these became the primary nightlife entertainment where they came together and built their networks of friends. As a result, the small bars in the station area were increasingly left behind with an aging clientele in the habit of hopping over to their favorite bars, whether during weekends or on ordinary weekdays. From the 1990s onwards, moreover, a second type of competitor appeared on the scene, this time commercial. A handful of gay-friendly mega clubs, commercial party formats, and mainstream mixed bars, such as Hessenhuis and Red \& Blue (both located in the redeveloped part of town to the north of the Skippers Quarter), made sure to expand their business by seeking to seize a big part of the pie of LGBT leisure culture. Particularly the younger crowd came to expect more spectacle than the small bars were able to offer, a tendency Armand and Roger explicitly deplored in a published interview: "It used to be enough that you opened the door and people came flooding in, whereas nowadays they grow tired of everything so soon. Things have to get more and more extravagant" (see Hellinck 2015: 16). As the couple of aging bar owners observed, this has had an atrophying effect on the cross-class (and cross-age) tradition of the local gay bar culture: "Back in the old days everybody was sitting together, intellectuals or not. You found yourself sitting next to a doctor or a lawyer, no matter: you were gay and you were being regarded as gay. Whereas nowadays such mixing is frowned upon: 'Oh, but he's only a laborer in the harbor.' That's the mentality that dominates today, more and more so" (Hellinck 2015: 16). To these rising pressures from outside players should be added more internal pressures in the 
form of the overall decline both of the area where the gay bars were clustered and of the quality of encounters inside the bars. National and international LGBT media had begun to report on a growing sense of unsafety and physical decay, especially in the main artery of the Van Schoonhovenstraat, which was said to be crime-ridden. "Rue de Vaseline" (Vaseline Street), as it was commonly nicknamed in gay circles, had gradually gained a sleazy reputation (Fig. 10.4).

With economic competition thus coming from two sides-one activist, one commercial-and the reputation of the area and its gay venues becoming ever more dubious, the bars in the station area came to seem old-fashioned, uneventful, sleazy, and unsafe, with dire consequences for their commercial viability. Nearly all of them went out of business as a result. This leaves us with a very different urban landscape today: the parties thrown by noncommercial players have in turn all but disappeared again (the mainstream Flemish LGBTIQ movement is now heavily subsidized and sports its own Rainbow House with a daily bar in a completely different part of the city, so that grassroots parties nowadays tend to be limited to the small, more radical, self-styled queer movement that has recently emerged), while the bigger commercial players are so few and intrinsically such self-sufficient institutions with their own

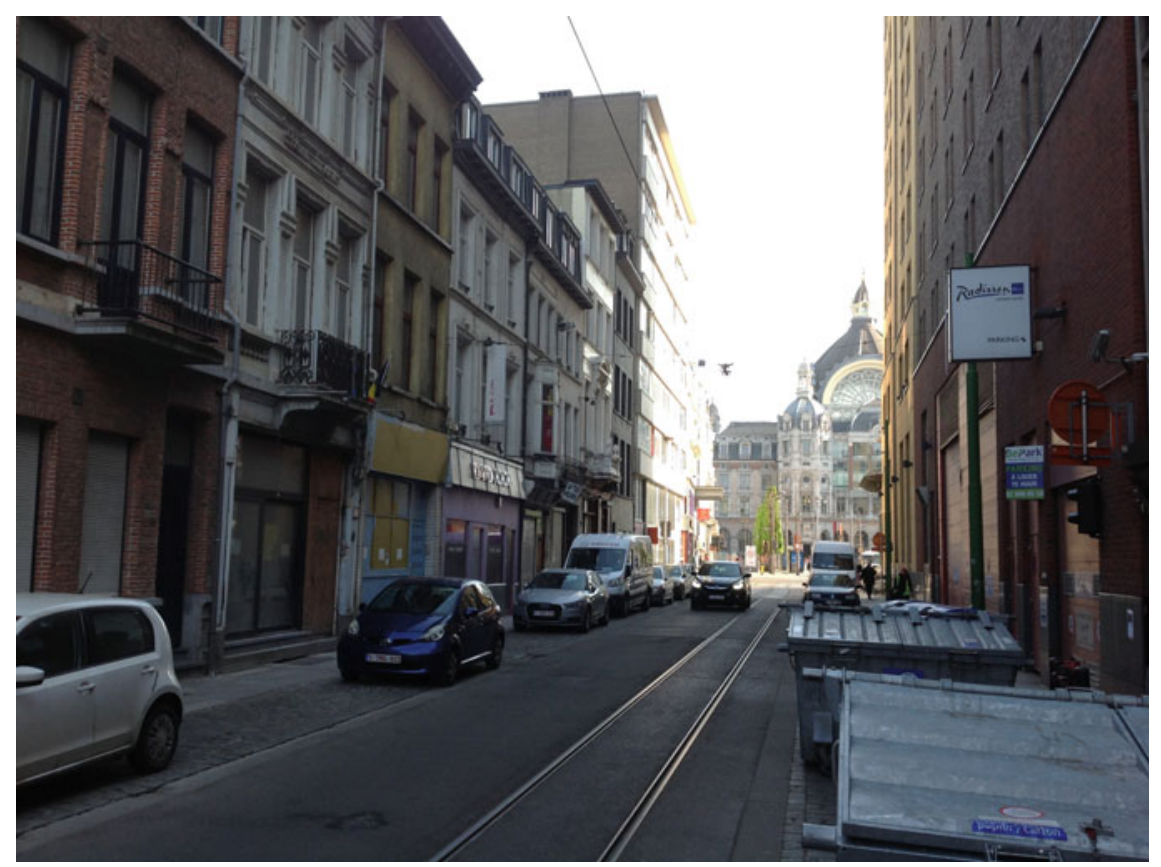

Fig. 10.4 The final stretch of the Van Schoonhovenstraat in the direction of Antwerp's monumental Central Station. Several of the buildings on the left used to house the gay bars that gave the street its nickname of Vaseline Street and that have since gone out of business (Source Image by Bart Eeckhout, April 2020) 
internal business logic that they cannot be said to build a recognizable spatial cluster in the city anymore.

An additional contextualizing paragraph on gentrification may be in order here as well, even if we include it so as to nuance its importance to our particular case study. Although Antwerp went through a process of modernist urban planning in the period after the Second World War, which also affected the Skippers Quarter (Loopmans and Van Den Broeck 2011), the streets harboring the gay bars near the train station remained largely untouched by it (Loopmans 2008). And while from 1983 onwards, after a decade of mostly economic crisis in the 1970s, urban planning in the city received a new impetus, again this focused on other areas of Antwerp, particularly those near the waterfront and the historical center. It was only by the 1990s, in fact, that a new phase of urban planning focused on the "livability" of poorer, inner-city neighborhoods. This slow and partial makeover gradually included the area to the north of the Central Station to which the cluster of gay bars belongs (Loopmans 2008). Yet even then, the actual material effects of such city-planned upgrading seem to postdate, by and large, the demise of the local world of gay bars, which was more driven by the logic described in the previous paragraphs than by any form of city planning or gentrification pushing the bars out of business.

All of these micro-changes on the ground within the city of Antwerp should obviously be framed again in a larger cultural context - that of the relatively quick shift in attitudes toward sexual and gender minorities within Western European societies overall, a shift that has arguably been even faster in Belgium (and especially Flanders) than in most of its neighboring countries. From being a deeply conservative, largely Catholic country, Belgium has leaped to the forefront of LGBTIQ rights in Europe in just a few decades' time, currently outranking all of its neighbors. ${ }^{12}$ This evolution has been most outspoken in Flanders, where the extent of secularization has made for the starkest historical contrast and the LGBTIQ movement has been particularly successful at organizing itself and exerting political influence. Especially as of the 1990s, sexual and gender minorities have become much more visible in the Flemish media and public life, thereby both stimulating and reflecting increasing social acceptance by the wider population. In these quickly transforming circumstances, the relatively exclusive, niche-specific, semi-public spaces of lesbian and gay bars that promised a safe haven in a largely hostile environment lost their raison d'être faster than anyone would have expected a few decades ago. In recent years, even center-right political coalitions that have seized power in Antwerp have embraced their LGBTIQ population and gone out of their way to market the entire city, rather than any particular part of it, as a gay-friendly tourist destination. Even ordinary zebra crossings have now been painted in rainbow colors.

Finally, at the global level, LGBTIQ life has been transformed by the virtualization of sexual networks in urban space as a result of new technologies. Digital, mobile, and social media allow for instantaneous contact across the globe, allowing LGBTIQs to

\footnotetext{
${ }^{12}$ See Borghs and Eeckhout (2010), Eeckhout and Paternotte (2011); and the annual Rainbow Map of Europe drawn up by ILGA-Europe, where for nearly a decade now Belgium has ranked around second place in all of Europe (https://rainbow-europe.org/country-ranking).
} 
connect across geographical boundaries beyond their immediate (urban) dwelling. At the same time, location-based services, in particular dating apps such as Grindr, allow LGBTIQs to identify and connect with other LGBTIQs within their urban or even rural contexts. Both tendencies, combined, have further eroded the need for separate LGBTIQ spaces as a way to get in touch with other LGBTIQ people and the appeal of a city like Antwerp as a magnet for LGBTIQ people.

\section{References}

Albrechts L, Lievois G (2004) The Flemish diamond: urban network in the making? Eur Plan Stud 12(3):351-370

Beachy R (2014) Gay Berlin: birthplace of a modern identity. Knopf, New York

Borghs P (2015) Holebipioniers: een geschiedenis van de holebi- en transgenderbeweging in Vlaanderen. 't Verschil, Antwerp

Borghs P, Eeckhout B (2010) LGB rights in Belgium, 1999-2007: a historical survey of a velvet revolution. Int J Law Policy Fam 24(1):1-28

Chauncey G (1995) Gay New York: gender, urban culture, and the making of the gay male world, 1890-1940. Basic Books, New York

Daems M (2010) Oudste homocafé gaat al meer dan een halve eeuw mee. De Magneet 14:4-5. https://issuu.com/thanhbeels/docs/dm_zomer_2010_low

David A, Meyntjens M (2009) Oud = Out: ervaringen van lesbische en biseksuele vrouwen, geboren voor 1945. Fonds Suzan Daniel/Uitgeverij ‘t Verschil, Gent/Antwerpen

De Bie M (2012) Interview by Rob Herreman. Antwerp, March 10

De Graef J (1973) Antwerpen bij nacht. De Dageraad, Antwerpen

Dupont W (2015) Free-floating evils: a genealogy of homosexuality in Belgium. PhD dissertation, University of Antwerp, Antwerp

Dupont W, Hofman E, Roelens J (eds) (2017) Verzwegen verlangen: een geschiedenis van homoseksualiteit in België. Uitgeverij Vrijdag, Antwerp

Eeckhout B, Paternotte D (2011) A paradise for LGBT rights? the paradox of Belgium. J Homosex 58(8): 1058-1084

Everaert A (2014) Interview by Rob Herreman. Antwerp, January 27

GUST (Ghent Urban Studies Team) (1999) The urban condition: space, community, and self in the contemporary metropolis. 010 Publishers, Rotterdam

Hellinck B (2002) Een halve eeuw (in) beweging. Een kroniek van de Vlaamse holebibeweging. Federatie Werkgroepen Homoseksualiteit, Gent

Hellinck B (2015) Een halve eeuw 'eigenaardig'. Het ondraaglijk besef. Nieuwsbrief van het Fonds Suzan Daniel 11:15

Hofman E (2017) The internalization of man: stigma, criminal justice and self in the Southern Netherlands, 1750-1830. PhD dissertation, KU Leuven, Leuven

Kegels H (2006) Biecht van twee mannen. Gopher, Utrecht

Kegels H (2008) De Flierefluiter. Gopher, Utrecht

Lampo J (2002) Tussen kaai en schip: de Antwerpse havenbuurt vóór 1885. Davidsfonds, Leuven

Lampo J (2011) Geschiedenis - Kroniek van het Schipperskwartier. https://janlampo.com/2011/11/ 26/kroniek-van-het-schipperskwartier/. Last accessed 17 June 2019

Loopmans M (2008) Relevance, gentrification and the development of a new hegemony on urban policies in Antwerp, Belgium. Urban Stud 45(12):2499-2519

Loopmans M, Van Den Broeck P (2011) Global pressures, local measures: the re-regulation of sex work in the Antwerp Schipperskwartier. Tijdschrift voor Economische en Sociale Geografie 102(5):548-561

Min E (2011) Rik Wouters: een biografie. Bezige Bij, Antwerpen 
Paoletti JB (2012) Pink and blue: telling the boys from the girls in America. Indiana University Press, Bloomington

Roelens J (2018) Citizens \& sodomites: perception and persecution of sodomy in the Southern low countries (1400-1700). PhD dissertation, Ghent University, Ghent

Sinfield A (1996) Diaspora and hybridity: queer identities and the ethnicity model. Textual Pract 10(2):271-293

Van den Heuvel D (2009) 'Even onder de onzen'? 'Homoseksuele' identiteitsvorming bij mannen in de stad Antwerpen tijdens de tweede helft van de twintigste eeuw. MA dissertation, University of Antwerp, Antwerp

Vanhaelewyn M (2008) Homotrots op een heterotrottoir: over holebimonumenten in België. BEGCHTP 20:233-258

Vincke J, Dewaele A, Van den Berghe W, Cox N (2006) Zzzip: een statistisch onderzoek met oog op het verzamelen van basismateriaal over de doelgroep holebi's. Ministerie van de Vlaamse gemeenschap gelijke kansen in Vlaanderen, Brussels

Winters J (2011) Tussen pot en pint. Het uitgaans(be)leven van lesbische en biseksuele vrouwen in Antwerpen vanaf de jaren '50. MA dissertation, Ghent University, Ghent

Bart Eeckhout is Professor of English and American Literature at the University of Antwerp, where he also chairs the Antwerp Research Institute for the Arts. He has authored and edited over thirty-five books and journal issues, including in the field of urban studies. As a board member of the Urban Studies Institute at the University of Antwerp, he collaborates with colleagues from a wide range of disciplines across the university. He has published about the confluence of architecture, urban planning, and sexuality from a queer studies perspective in various books and journals.

Rob Herreman has a professional bachelor's degree in Music (2000, Hogeschool Gent) and a master's degree in Musicology (2004, Catholic University of Leuven). He is currently finishing a $\mathrm{PhD}$ at the University of Antwerp on the recent history of lesbian and gay music in Antwerp. His research and publications focus on the various relationships between music and sexuality from a musicological perspective.

Alexander Dhoest is Professor of Media Studies at the University of Antwerp, where he also chairs the Media, Policy \& Culture research group as well as the Antwerp Gender and Sexuality Studies Network. He has published over sixty peer-reviewed articles, over thirty book chapters, and written or edited seven books on a range of topics related to media and identity, focusing on ethnocultural identity, sexuality, and intersectionality. He coedited LGBTQs, Media and Culture in Europe (2017, Routledge) with Lukasz Sculz and Bart Eeckhout.

Open Access This chapter is licensed under the terms of the Creative Commons Attribution 4.0 International License (http://creativecommons.org/licenses/by/4.0/), which permits use, sharing, adaptation, distribution and reproduction in any medium or format, as long as you give appropriate credit to the original author(s) and the source, provide a link to the Creative Commons license and indicate if changes were made.

The images or other third party material in this chapter are included in the chapter's Creative Commons license, unless indicated otherwise in a credit line to the material. If material is not included in the chapter's Creative Commons license and your intended use is not permitted by statutory regulation or exceeds the permitted use, you will need to obtain permission directly from the copyright holder. 